\title{
Wildlife attacks hinder conservation efforts
}

Rex Dalton, San Diego

Incidents such as the untimely death of Mark Jeffrey Reynolds, a 35-year-old cyclist who was disembowelled by a puma in the Whiting Ranch Wilderness Park near Los Angeles on 8 January, don't make it any easier for biologists who are trying to study and conserve predator species in the American West.

Yet efforts to conserve pumas, wolves, grizzly bears and other predator species have continued to gain momentum. Researchers hope that more thorough studies of animal behaviour will reduce the number of accidents and maintain the fragile public support for the conservation of even the fiercest predators.

Only days after Reynolds and another cyclist, Anne Hjelle, who survived, were attacked, researchers at the University of California, Davis, released what they say is the most comprehensive study yet of interactions between pumas and people.

"Ultimately, it is up to people to decide if they want to share the environment with an animal that can kill them," says Walter Boyce, director of the university's Wildlife Health Center and leader of the study. "Attacks are rare, but there is no guarantee of safety."

Boyce and colleagues charted the lives of 20 pumas for 3 years in the Cuyamaca Rancho State Park near San Diego, close to where a birdwatcher was killed by a puma in 1994 .
The observations, made using radiocollars that beamed the pumas' locations to a satellite, showed that the animals hunted deer and bighorn sheep, and cached their kills within a few hundred metres of people's homes and a girls' camp. But they found that the pumas were careful to avoid humans, and were most active between dusk and dawn.

Boyce says that his group's findings will help visitors to the pumas' territory make informed decisions about their own safety. Safety recommendations from the study are being widely circulated in California, where puma populations have been growing in protected wilderness.

Pumas are abundant in California, but rarer predators are the subject of contentious protection battles. For example, the grey wolf, which was wiped out in the United States 75 years ago, has been successfully reintroduced since 1995 in Montana, Idaho and Wyoming.

Conservationists see this reintroduction as one of the great successes of the 1973 Endangered Species Act (ESA). But ranchers, hunters and associated businesses are objecting to the growing population of grey wolves outside the Yellowstone National Park, where the conservation effort started.

The US Fish and Wildlife Service (FWS), which controls the effort, was prepared to relax ESA protection of the wolf in the three states if they came up with satisfactory plans to conserve the species on their own. Earlier this month, FWS officials approved the plans offered by Montana and Idaho, but rejected that of Wyoming. The plan drawn up by this staunchly conservative state would have allowed widespread killing of the wolves in some areas.

Wyoming officials say that a conservation effort would cost $\$ 700,000$ a year, and that the federal government should pay. A similar dispute is expected to arise later this year, when the FWS will try to transfer responsibility for conservation of the grizzly bear to Wyoming and other western states. " www.vetmed.ucdavis.edu/whc/scp/ mnt_lion.htm

\section{$\mathrm{NIH}$ acts to quench 'conflict of interest' allegations}

Erika Check, Washington

The National Institutes of Health (NIH)

looks set to ensure fuller disclosure of

dealings that its senior staff have with

private companies.

Elias Zerhouni, director of the biomedical research agency, told a congressional hearing on 22 January that the agency would take steps to guard against conflict of interest, or the perception of it, among its senior staff. "I have reached the conclusion that the NIH must make changes that will appropriately restrict current practices," he said.

The hearing was held in response to an investigation by the Los Angeles Times, which reported on 7 December last year that some senior NIH scientists were receiving consulting payments from, or held shares in, biotechnology companies that were benefiting from grants or other decisions that the scientists could have influenced (see Nature 426, 739; 2003). The newspaper noted that, under rules established in 1995 , the scientists were not required to publicly disclose these interests.

Zerhouni also announced that a panel co-chaired by Bruce Alberts, president of the National Academy of Sciences, and Norman Augustine, chairman of the Lockheed Martin Corporation, would look into the allegations and report within 90 days on steps the agency could take to guard against future conflicts of interest.

Senator Arlen Specter (Republican, Pennsylvania), chair of the Senate appropriations subcommittee that held the hearing, said the allegations raised serious issues for the agency. "I believe there have to be substantial remedial steps taken to ensure that a wall of separation between public duties and private compensation is maintained," Specter said.

Observers say it is now likely that the

US Department of Health and Human

Services, of which the NIH is part, will change the rules that currently shield some agency scientists from public scrutiny. On 12 January, health-department lawyer Edgar Swindell sent a letter to the Office of Government Ethics, which oversees ethics regulations for the US federal government. He requested that senior officials at the NIH's 27 centres and institutes be required to disclose their sources of income to the public. At the Senate hearing, an official from the ethics office signalled that she would approve this request.

According to documents released by the health department, Swindell made a similar request six years ago which the ethics office rejected on technical grounds. 